\title{
Short term effects of Centella asiatica on methylparathion induced toxicity on different regions of the brain in rat, Rattus norvegicus
}

\author{
Gladies Kezia J*, Lucky R, Nausheen Dawood, Dawood sharief., \\ Joyce Priyakumari.C
}

\begin{abstract}
In the present study, Methyl parathion an organophosphate compound has been induced to the rats to study the activity of acetylcholinesterase on different regions of the brain for short term effects i.e., for 28 days and then an antidote Centella asiatica was given to the rats which were induced with methylparathion.

Keywords: AChE, Brain, Centella asiatica, Methyl parathion, Organophosphate compound,
\end{abstract}

\section{Introduction}

Organophosphorus (OP) compounds are a major component of many pesticides with widespread use in both agricultural and domestic situations (Kalender et al., 2006.) Organophosphate pesticides have increased in use, because they are less damaging to the environment and they are less persistent than organochlorine pesticides. OP insecticides elicit toxicity by inhibiting the enzyme acetylcholinesterase (Karanth et al., 2004, Pope, 1999, Ecobichon, 1996 and Gallo and Lawryk, 1991). With extensive AChE inhibition, the neurotransmitter acetylcholine (Ach) accumulates in the synapses of the central and peripheral nervous system, which in turn leads to over stimulation of postsynaptic cholinergic receptors and signs of cholinergic neurotoxicity (Karanth et al., 2004, Savolainen, 2001, Ecobiochon 1996 and Silver, 1974). Phosphorothioate parent molecules are non-toxic, but after undergoing metabolism they yield oxon (phosphates) derivatives (Norman et al., 1974 and Neal, 1967) that are capable of inhibiting AChE (Saunders and Harper, 1994 and Marrs, 1993). Inhibition of AChE results in accumulation of acetylcholine in certain synapses and neuromuscular plates, provoking a steady depolarization of the affected neurons; this might lead to death due to respiratory failure (Lima et al., 1996, Marrs, 1993, Koelle, 1992 and Rickett et al., 1986).

\section{Materials And Methods}

Adult male albino rats Rattus norvegicus of Wistar strain weighing about 120-150 g were obtained from the King's Institute, Guindy, Chennai, India. The animals were housed in plastic cages, fed standard laboratory diet and water ad libitum. Rats were exposed to $12 \mathrm{~h}$ light $/ 12 \mathrm{~h}$ dark. Rat is the ideal animal model for laboratory observations. Adequate brain tissue is available for experimental studies. Animals were quarantined for 10 days before being randomized into experimental groups of 4 animals per cage. Animals were maintained according to the principle and guidelines of the Committee for the Purpose of Control and Supervision of Experiments on Animals (IAEC No.945/c/01/01/06) under the supervision of Animal Ethical Committee.

\section{CHEMICALS}

Methyl parathion purity $99.8 \%$ was obtained from Bayer Science Crops, Mumbai, India. This was mixed with groundnut oil and given to the rats, because methyl parathion dissolves in groundnut oil.

\section{PLANT MATERIALS}

Centella asiatica was selected for the present study, the whole plant was collected, shade dried and finely ground with grinder. The finely powdered material was mixed with water and administered to the experimental rats.

\section{EXPERIMENTAL DESIGN}

The animals were separated into 5 groups and each group consisted of 6 animals.

Group I: served as control

Group II: Animals were fed with methyl parathion (MP) alone

Group III: Animals were fed with aqueous Centella asiatica (CA)

Group IV: Animals were fed with both methyl parathion (MP) and Centella asiatica (CA)

Group V: Animals were administered with groundnut oil. This served as negative control 
The $\mathrm{LD}_{50}$ value for methyl parathion is $14 \mathrm{mg} / \mathrm{kg}$ body weight according to Casarett, (1980). For acute toxicity study $1 / 3^{\text {rd }}$ of the $\mathrm{LD}_{50}$ value was taken, and mixed along with groundnut oil and administered to the rats. For short and long term study, care was taken so that the value didn't exceed the $\mathrm{LD}_{50}$ value.

\section{COLLECTION OF TISSUE SAMPLES}

The rats were starved prior to the experiment for a period of $24 \mathrm{~h}$. Later they were fed with water. Both control and experimental rats were sacrificed by decapitation with anaesthetization. The tissues selected for the present study were the different regions of the brain (Olfactory lobes (OL), Optic lobes (OPL), Cerebrum (CB), Cerebellum (CL), Midbrain (MB) and Medulla oblongata (MO)), liver (Liv) and kidney (Kid) and in non-target organs like thymus(Thy), spleen (Spl), bone marrow (BM) and blood (Bld). The brain was removed as rapidly as possible and washed several times in ice cold saline and cleaned to remove blood clots and meninges following the procedure of Vijayan and Brownson, (1975).

\section{Methods \\ ESTIMATION OF ACTEYLCHOLINESTERASE (ACHE)}

Different regions of the brain and blood sample were taken for the estimation of $\mathrm{AChE}$ as per the method of Ellman et al., (1961).

\section{PRINCIPLE}

Measurement of the rate of production of the choline as acetylcholine is hydrolyzed. This is accomplished by the continuous reaction of thiol with 5, 5-dithio-bis-2 nitro-benzoate ion to produce the yellow anion of 5-thio-2-nitro benzoic acid; the rate of colour production is measured at $412 \mathrm{~nm}$ spectrophotometrically.

Acetyl thiocholine $\longrightarrow$ (enzyme) thiocholine + acetate

Thiocholine + dithiobis 2-nitro-benzoate $\longrightarrow$ yellow colour

\section{REAGENTS}

1. Phosphate buffer-(0.1M,pH 7 and $\mathrm{pH} 8)$

2. Dithio-bis-nitrobenzoic acid (DTNB) was prepared by dissolving $36.9 \mathrm{mg}$ of DTNB in $10 \mathrm{ml}$ of $0.1 \mathrm{M}$ phosphate buffer of $\mathrm{pH} 7$ and $15 \mathrm{mg}$ of sodium carbonate was added.

3. Substrate $-21.67 \mathrm{mg}$ of acetylcholine iodide was dissolved in $1 \mathrm{ml}$ of double distilled water

4. Inhibitors - Eserine sulphate ( $10^{-4}$ molarity for brain tissues) and quinidine sulphate (blood).

\section{ESTIMATION OF ACHE IN DIFFERENT REGIONS OF THE BRAIN}

After decapitation, the brain was removed following the procedure mentioned in 2.1.5. The regions were separated into OLB, CB, OPL, CL, MB and MO following the method of Vijayan and Brownson, (1975).The saline cleaned and weighed tissues of the different brain regions of Rattus norvegicus were homogenized in $0.1 \mathrm{M}$ phosphate buffer (pH.8) at a concentration of $20 \mathrm{mg} / \mathrm{ml}$, by using a pre chilled glass homogenizer kept in a beaker containing ice-cubes. The homogenate was centrifuged at $1500 \mathrm{rpm}$ for 5 minutes. The supernatant was used as the enzyme source.

\section{PROCEDURE}

$0.4 \mathrm{ml}$ of the sample was taken in a cuvette containing $2.6 \mathrm{ml}$ of $0.1 \mathrm{M}$ phosphate buffer (pH.8). To this, was added $0.1 \mathrm{ml}$ of DTNB reagent and mixed well. The absorbance was set to 'zero' at $412 \mathrm{~nm}$ in the spectrophotometer. The reaction was started by adding $0.02 \mathrm{ml}$ of the acetyl-thio choline iodide substrate to the mixture and mixed well. The readings were recorded for every minute upto 5 minutes. $0.1 \mathrm{ml}$ of eserine sulphate $\left(10^{-4} \mathrm{M}\right)$ a specific AChE inhibitor was added to another cuvette containing $0.4 \mathrm{ml}$ of homogenate, $2.5 \mathrm{ml}$ of $0.1 \mathrm{M}$ phosphate buffer ( $\mathrm{pH} 8.0$ ) and mixed well. Then $0.1 \mathrm{ml}$ of DTNB reagent was added and mixed thoroughly. The absorbance was set to "zero' at $412 \mathrm{~nm}$ as stated earlier. Then $0.02 \mathrm{ml}$ of the substrate was added to the cuvette and mixed well. The readings were recorded for 5 minutes at an interval of 1 minute with inhibitor value being substracted from the recording without inhibitor. The enzyme activity was expressed as moles of substrate hydrolyzed/min/g tissue.

The enzyme activity was calculated using the formula given below:

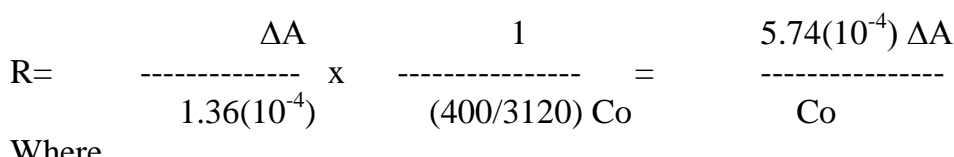


$\mathrm{R}=$ rate of enzyme activity in moles of substrate hydrolyzed $/ \mathrm{min} / \mathrm{g}$ of tissue

$\mathrm{A}=$ change in absorbance $/ \mathrm{min}$

$\mathrm{Co}=$ Original concentration of tissue $(\mathrm{mg} / \mathrm{ml})$

The enzyme activity was represented in moles of acetylthiocholine hydrolyzed $/ \mathrm{min} / \mathrm{gm}$ of tissue.

\section{STATISTICAL ANALYSIS}

The data obtained from various studies were subjected to statistical analysis using SPSS package. Student's t-test was applied for toxicity studies. The values are expressed as the mean $\pm \mathrm{SD}$ and the difference between groups were statistically analyzed using one way analysis of variance (ANOVA)

\section{Results}

In the present study short term oral toxicity of the organophosphate (OP), i.e., Methyl Parathion (MP) on rats Rattus norvegicus were analyzed and the effect of Centella asiatica (CA) an antidote was studied.

$\mathrm{LD}_{50}$ value of Methyl Parathion $=14 \mathrm{mg} / \mathrm{kg}$ body weight.

Centella asiatica $=200 \mathrm{mg} / \mathrm{kg}$ body weight.

The doses of MP and CA administered orally were well within the $\mathrm{LD}_{50}$ value.

\section{SHORT TERM ORAL TOXICITY STUDY}

Acetylcholinesterase (AChE) activity in the different regions of the brain of Rattus norvegicus due to short term oral toxicity on $7^{\text {th }}, 14^{\text {th }}, 21^{\text {st }}$ and $28^{\text {th }}$ day is shown in table $-1,2,3$ and 4 and figure $-1,2,3$ and 4 .

The change in the level of AChE activity in the OL of Rattus norvegicus on $7^{\text {th }}$ day is illustrated in table -1 and figure - 1 . Group II animals showed an increase in the enzyme activity $\left(0.57 \times 10^{-6}\right.$ moles $\left.\min ^{-1} \mathrm{~g}^{-1}\right)$ and the increase is significant at $\mathrm{p}<0.001$ level while group III and IV did not show enzyme activity. Group V remains the same as that of Group I $\left(0.25 \times 10^{-6}\right.$ moles $\left.\min ^{-1} \mathrm{~g}^{-1}\right)$ when group IV was compared with group II, it showed a decrease and the decrease is significant at $p<0.001$ level. The rate of AChE activity in the OP of group II showed a decrease $\left(0.28 \times 10^{-6}\right.$ moles $\left.\min ^{-1} \mathrm{~g}^{-1}\right)$ and is significant at $\mathrm{p}<0.001$ level. Group V remains the same as that of group I (table - 1, figure - 1).

There was no AChE activity in CB of Group II and III. Group IV and V did not show any enzymatic change when compared with group I while group IV showed a significant increase at $p<0.001$ level when compared with group II (table - 1, figure - 1).

CL of group II, III and IV did not show any activity. In group V the AChE activity remains the same as that of group I (table - 1, figure - 1).

MB of group II and III did not show any enzymatic changes. Group IV and V did not show any significant change when compared with group I. group IV showed a significant increase at $p<0.001$ level when compared with group II (table - 1, figure - 1). The rate of AChE activity in MO of group II and V did not show significant change. There was no enzyme activity group III and IV when compared with group I (table -1, figure - 1).AChE activity in OL of Rattus norvegicus on $14^{\text {th }}$ day is illustrated in table -2 and figure - 2. Group II and III the activity increases $\left(0.28 \times 10^{-6}\right.$ moles $\min ^{-1} \mathrm{~g}^{-1}$ and $0.28 \times 10^{-6}$ moles $\left.\min ^{-1} \mathrm{~g}^{-1}\right)$ and the increase is significant at $\mathrm{p}<0.001$ level. Group V remains the same $\left(0.25 \times 10^{-6}\right.$ moles $\left.\mathrm{min}^{-1} \mathrm{~g}^{-1}\right)$ as that of group I $\left(0.25 \times 10^{-6}\right.$ moles $\mathrm{min}^{-1}$ $\left.\mathrm{g}^{-1}\right)$.

AChE activity in OP of Rattus norvegicus on $14^{\text {th }}$ day is illustrated in table -2 and figure - 2. Group II, III and IV showed a decrease in the AChE activity and the decrease is significant at $p<0.001$ level. Group V did not show any significant change $\left(0.83 \times 10^{-5}\right.$ moles $\left.\min ^{-1} \mathrm{~g}^{-1}\right)$ when compared with group I $\left(0.83 \times 10^{-5}\right.$ moles $\mathrm{min}^{-1}$ $\mathrm{g}^{-1}$ ). Group IV did not show any significant change when compared with group II.

AChE activity in CB of Rattus norvegicus on $14^{\text {th }}$ day is illustrated in table - 2 and figure - 2. Group II showed significant decrease $\left(0.27 \times 10^{-7}\right.$ moles $\left.\min ^{-1} \mathrm{~g}^{-1}\right)$ at $\mathrm{p}<0.001$ level. Group III and IV did not show any activity. Group V did not show any significant change when compared with group I.

AChE activity in CL of Rattus norvegicus on $14^{\text {th }}$ day is illustrated in table - 2 and figure - 2. Group II showed a significant increase $\left(0.57 \times 10^{-6}\right.$ moles $\left.\min ^{-1} \mathrm{~g}^{-1}\right)$ at $\mathrm{p}<0 / 001$ level. Group III and IV did not show any activity. Group V did not show any significant change when compared with group I.

$\mathrm{AChE}$ activity in MB of Rattus norvegicus on $14^{\text {th }}$ day is illustrated in table - 2 and figure - 2. Group II, IV and V remains the same when compared with group I. Group IV did not show any change when compared with group II.

The change in the level of AChE activity in MO of Rattus norvegicus on $14^{\text {th }}$ day is illustrated in table 2 and figure - 20 Group II increases $\left(0.34 \times 10^{-6}\right.$ moles $\left.\min ^{-1} \mathrm{~g}^{-1}\right)$ and the increase is significant at $\mathrm{p}<0.001$ level. Group III and IV showed no enzyme activity. In group V the activity remains the same as that of Group I.

The change in the level of AChE activity of OL of Rattus norvegicus on $21^{\text {st }}$ day is illustrated in table 3 and figure - 3. Group III and IV did not show any activity. Group II and V remains the same when compared with group I. 
The change in the level of AChE activity in OP of Rattus norvegicus on $21^{\text {st }}$ day is illustrated in table 3 and figure - 3. Group II and IV did not show any enzyme activity. Group III showed a significant decrease $\left(0.28 \times 10^{-6}\right.$ moles $\left.\min ^{-1} \mathrm{~g}^{-1}\right)$ at $\mathrm{p}<0.001$ level. Group $\mathrm{V}$ did not show any significant change when compared with group I.

The rate of AChE activity in $\mathrm{CB}$ of Rattus norvegicus on $21^{\text {st }}$ day is illustrated in table - 3 and figure 3. Group II, IV and V did not show any significant change, Group III showed no activity when compared with group I $\left(0.28 \times 10^{-6}\right.$ moles $\left.\min ^{-1} \mathrm{~g}^{-1}\right)$. Group IV did not show any changes when compared with group II.

The change in the level of AChE activity of CL in Rattus norvegicus on $21^{\text {st }}$ day is illustrated in table 3 and figure - 3. Group II increases $\left(0.57 \times 10^{-6}\right.$ moles $\left.\min ^{-1} \mathrm{~g}^{-1}\right)$ and is statistically significant at $\mathrm{p}<0.001$ level. Group III showed no activity. Group IV and V did not show any significant change when compared with group I. Group IV showed significant decrease at $\mathrm{p}<0.001$ level when compared with group II.

The change in the level of $\mathrm{AChE}$ activity in $\mathrm{MB}$ of Rattus norvegicus on $21^{\text {st }}$ day is illustrated in table 3 and figure - 3. Group II increases $\left(0.57 \times 10^{-6}\right.$ moles $\left.\min ^{-1} \mathrm{~g}^{-1}\right)$ and is statistically significant at $\mathrm{p}<0.001$ level. Group III showed no activity. Group IV and V did not show any significant change when compared with group I. Group IV showed significant decrease at $\mathrm{p}<0.001$ level when compared with group II.

The change in the level of AChE activity in MO of Rattus norvegicus on $21^{\text {st }}$ day is illustrated in table 3 and figure - 3. Group II increases $\left(0.57 \times 10^{-6}\right.$ moles $\left.\min ^{-1} \mathrm{~g}^{-1}\right)$ and is statistically significant at $\mathrm{p}<0.001$ level. Group III and IV did not show any enzyme activity. Group V did not show any significant change when compared with group I. Group IV showed a significant change at $p<0.001$ level when compared with group II.

The change in the level of AChE activity in OL of Rattus norvegicus on $28^{\text {th }}$ day is illustrated in table 4 and figure - 4. Group II did not show any enzyme activity. Group III and IV showed an increase $\left(0.28 \times 10^{-}\right.$ ${ }^{6}$ moles $\min ^{-1} \mathrm{~g}^{-1}$ ) and is statistically significant at $\mathrm{p}<0.001$ level. Group V remains the same as that of Group I. Group IV showed a significant increase at $\mathrm{p}<0.001$ level when compared with group II.

The rate of AChE activity in OP of Rattus norvegicus on $28^{\text {th }}$ day is illustrated in table - 4 and figure 4. Group II, III and IV showed a decrease and is statistically significant at $p<0.001$ level. Group V did not show any significant change when compared with group I. Group IV did not show any significant change when compared with group II.

The change in the level of AChE activity in $\mathrm{CB}$ of Rattus norvegicus on $28^{\text {th }}$ day is illustrated in table 4 and figure - 4. Group II, III, IV and V did not show any significant change when compared with group I. Group II and IV did not show any significant change when compared with group III.

The change in the level of AChE activity in CL of Rattus norvegicus on $28^{\text {th }}$ day is illustrated in table 4 and figure - 4. Group III, IV and V did not show any significant change. Group II showed no activity when compared with group I. Group IV showed no significant change when compared with group II.

The rate of AChE activity in MB of Rattus norvegicus on $28^{\text {th }}$ day is illustrated in table - 4 and figure 4. Group III, IV and V did not show any significant change. Group II showed no activity when compared with group I $\left(0.28 \times 10^{-6}\right.$ moles $\left.\mathrm{min}^{-1} \mathrm{~g}^{-1}\right)$. Group IV showed significant increase at $\mathrm{p}<0.001$ level when compared with group II.

The rate of AChE activity in MO of Rattus norvegicus on $28^{\text {th }}$ day is illustrated in table - 4 and figure 4. Group II, III, IV and V did not show any significant change when compared with group I $\left(0.28 \times 10^{-6}\right.$ moles $\min ^{-1} \mathrm{~g}^{-1}$ ). Group IV did not show any significant change when compared with group II.

\section{Discussion:}

The results of the short term study (28 days) has revealed that there is a significant decrease in group II of OL, group II,III of OP, group II of CB on $14^{\text {th }}$ day, group III of OP, and group IV of CL on $21^{\text {st }}$ day and group II,III and IV of OP on $28^{\text {th }}$ day. The decrease in the AChE activity might be due to the effect of MP thereby leading to inhibition of AChE activity. The present study was in accordance with Dikshith et al., (1982) who reported that inhibition of AChE might decrease the activity, which was also noted in goats treated with quinalphos and a significant increase is noted in group II of OL on $7^{\text {th }}$ day, II and III of OL, II of MO on $14^{\text {th }}$ day, group II of CL on $21^{\text {st }}$ day group II of MB and MO on $28^{\text {th }}$ day. It may be pointed out that there exists a significant increase in the activity of AChE in brain tissue in toto (Sayim et al., 2005 and Aziz et al, 2001 and Husain et al., 1996) which is also supported by the studies of Rao et al., (2005) who reported that oral administration of C.asiatica also increased the Ach content and Acetylcholinesterase activity in the rat brain. 
Short term effects of Centella asiatica on methylparathion induced toxicity on different regions of the

Table - 1 Acetylcholinesterase (AChE) activity in the different regions of the brain Of Rattus norvegicus due to short term oral toxicity at $7^{\text {th }}$ day

\begin{tabular}{|c|c|c|c|c|c|c|}
\hline Parameter & OL & OP & CB & CL & MB & MO \\
\hline Group I & $\begin{array}{l}0.25 \times 10^{-6} \\
\pm 0.25 \times 10^{-08}\end{array}$ & $\begin{array}{l}0.83 \times 10^{-5} \\
\pm 0.26 \times 10^{-07}\end{array}$ & $\begin{array}{l}0.28 \times 10-6 \\
\pm 0.2 \times 10^{-08}\end{array}$ & $\begin{array}{l}2.8 \times 10^{-6} \\
\pm 0.25 \times 10^{-08}\end{array}$ & $\begin{array}{l}0.28 \times 10^{-6} \\
\pm 0.2 \times 10^{-08}\end{array}$ & $\begin{array}{l}0.28 \times 10^{-6} \\
\pm 0.2 \times 10^{-08}\end{array}$ \\
\hline Group II & $\begin{array}{l}0.57 \times 10^{-6} \\
\pm 0.2 \times 10^{-08} \mathrm{a}^{* * *}\end{array}$ & $\begin{array}{l}2.8 \times 10^{-6} \\
\pm 0.25 \times 10^{-} \\
{ }^{08} \mathrm{a}^{* * *}\end{array}$ & $\begin{array}{l}0 \\
0\end{array}$ & $\begin{array}{l}0 \\
0\end{array}$ & $\begin{array}{l}0 \\
0\end{array}$ & $\begin{array}{l}2.8 \times 10^{-6} \\
\pm 0.25 \times 10^{-08} \mathrm{aNS}\end{array}$ \\
\hline Group III & $\begin{array}{l}0 \\
0\end{array}$ & $\begin{array}{l}0 \\
0\end{array}$ & $\begin{array}{l}0 \\
0\end{array}$ & $\begin{array}{l}0 \\
0\end{array}$ & $\begin{array}{l}0 \\
0\end{array}$ & $\begin{array}{l}0 \\
0\end{array}$ \\
\hline Group IV & $\begin{array}{l}0 \\
0\end{array}$ & $\begin{array}{l}0 \\
0\end{array}$ & $\begin{array}{l}2.8 \times 10^{-6} \\
\pm 0.25 \times 10^{-} \\
{ }^{00} \mathrm{aNSb} * * *\end{array}$ & $\begin{array}{l}0 \\
0\end{array}$ & $\begin{array}{l}2.8 \times 10^{-6} \\
\pm 0.25 \times 10^{-} \\
{ }^{08} \mathrm{aNSb}^{* * *}\end{array}$ & $\begin{array}{l}0 \\
0\end{array}$ \\
\hline Group V & $\begin{array}{l}2.5 \times 10^{-6} \\
\pm 0.25 \times 10^{-08} \mathrm{aNS}\end{array}$ & $\begin{array}{l}0.83 \times 10^{-5} \\
\pm 0.2 \times 10^{-08} \mathrm{aNS}\end{array}$ & $\begin{array}{l}2.8 \times 10^{-6} \\
\pm 0.25 \times 10^{-08} \mathrm{aNS}\end{array}$ & $\begin{array}{l}2.8 \times 10^{-6} \\
\pm 0.25 \times 10^{-08} \mathrm{aNS}\end{array}$ & $\begin{array}{l}2.8 \times 10^{-6} \\
0.25 \times 10^{-08} \pm \mathrm{aNS}\end{array}$ & $\begin{array}{l}2.8 \times 10^{-6} \\
\pm 0.25 \times 10^{-08} \mathrm{aNS}\end{array}$ \\
\hline
\end{tabular}

Values represent mean \pm SD of 6 animals

$* * * \mathrm{p}<0.001 ; * * \mathrm{p}<0.01 ; * \mathrm{p}<0.05 ;{ }^{\mathrm{NS}}$ Non-significant

a when compared with group I $b$ when compared with group II

Table - 2 Acetylcholinesterase (AChE) activity in the different regions of the brain Of Rattus norvegicus due to short term oral toxicity at $14^{\text {th }}$ day

\begin{tabular}{|c|c|c|c|c|c|c|}
\hline Parameter & OL & OP & CB & CL & MB & MO \\
\hline Group I & $\begin{array}{l}0.25 \times 10^{-6} \\
\pm 0.25 \times 10^{-08}\end{array}$ & $\begin{array}{l}0.83 \times 10^{-5} \\
\pm 0.26 \times 10^{-07}\end{array}$ & $\begin{array}{l}2.8 \times 10^{-6} \\
\pm 0.25 \times 10^{-08}\end{array}$ & $\begin{array}{l}2.8 \times 10^{-6} \\
\pm 0.25 \times 10^{-08}\end{array}$ & $\begin{array}{l}2.8 \times 10^{-6} \\
\pm 0.25 \times 10^{-08}\end{array}$ & $\begin{array}{l}2.8 \times 10^{-6} \\
\pm 0.25 \times 10^{-08}\end{array}$ \\
\hline Group II & $\begin{array}{l}2.8 \times 10^{-6} \\
\pm 0.25 \times 10^{-08} \mathrm{a}^{* * *}\end{array}$ & $\begin{array}{l}2.8 \times 10^{-6} \\
\pm 0.25 \times 10^{-08} \mathrm{a}^{* * *}\end{array}$ & $\begin{array}{l}2.7 \times 10^{-6} \\
\pm 0.25 \times 10^{-08} \mathrm{a}^{* * *}\end{array}$ & $\begin{array}{l}5.7 \times 10^{-6} \\
\pm 0.25 \times 10^{-08} \mathrm{a}^{* * *}\end{array}$ & $\begin{array}{l}2.8 \times 10^{-6} \\
\pm 0.25 \times 10^{-08} \mathrm{a}^{\mathrm{NS}}\end{array}$ & $\begin{array}{l}0.34 \times 10^{-06} \\
\pm 0.2 \times 10^{-08} \mathrm{a}^{* * *}\end{array}$ \\
\hline Group III & $\begin{array}{l}2.8 \times 10^{-6} \\
\pm 0.25 \times 10^{-08} \mathrm{a}^{* * *}\end{array}$ & $\begin{array}{l}2.8 \times 10^{-6} \\
\pm 0.25 \times 10^{-08} \mathrm{a}^{* * *}\end{array}$ & $\begin{array}{l}0 \\
\pm 0\end{array}$ & $\begin{array}{l}0 \\
\pm 0\end{array}$ & $\begin{array}{l}0 \\
\pm 0\end{array}$ & $\begin{array}{l}0 \\
\pm 0\end{array}$ \\
\hline Group IV & $\begin{array}{l}0 \\
\pm 0\end{array}$ & $\begin{array}{l}2.8 \times 10^{-6} \\
\pm 0.25 \times 10^{-} \\
{ }^{08} \mathrm{a}^{* * *} \mathrm{~b}^{\mathrm{NS}}\end{array}$ & $\begin{array}{l}0 \\
\pm 0\end{array}$ & $\begin{array}{l}0 \\
\pm 0\end{array}$ & $\begin{array}{l}2.8 \times 10^{-6} \\
\pm 0.25 \times 10^{-08} a^{N S} \\
b^{N S}\end{array}$ & $\begin{array}{l}0 \\
\pm 0 \mathrm{a}^{* * *} \mathrm{~b}^{* * *}\end{array}$ \\
\hline Group V & $\begin{array}{l}0.25 \times 10^{-6} \\
\pm 0.25 \times 10^{-08} \mathrm{aNS}\end{array}$ & $\begin{array}{l}0.83 \times 10^{-5} \\
\pm 0.26 \times 10^{-07} \text { a NS }\end{array}$ & $\begin{array}{l}2.8 \times 10^{-6} \\
\pm 0.25 \times 10^{-08} \mathrm{aNS}\end{array}$ & $\begin{array}{l}2.8 \times 10^{-6} \\
\pm 0.25 \times 10^{-08} \mathrm{a}^{\mathrm{NS}}\end{array}$ & $\begin{array}{l}2.8 \times 10^{-6} \\
\pm 0.25 \times 10^{-08} \mathrm{a}^{\mathrm{NS}}\end{array}$ & $\begin{array}{l}2.8 \times 10^{-6} \\
\pm 0.25 \times 10^{-08} \mathrm{a}^{\mathrm{NS}}\end{array}$ \\
\hline
\end{tabular}

Values represent mean \pm SD of 6 animals, $* * * p<0.001 ; * * \mathrm{p}<0.01 ; * \mathrm{p}<0.05$; ${ }^{\mathrm{NS}}$ Non-significant, when compared with group I $b$ when compared with group II

Table - 3 Acetylcholinesterase (AChE) activity in the different regions of the brain Of Rattus norvegicus due to short term oral toxicity at $21^{\text {st }}$ day

\begin{tabular}{|c|c|c|c|c|c|c|}
\hline Parameter & OL & OP & CB & CL & MB & MO \\
\hline Group I & $\begin{array}{l}0.25 \times 10^{-6} \\
\pm 0.25 \times 10^{-08}\end{array}$ & $\begin{array}{l}0.83 \times 10^{-5} \\
\pm 0.26 \times 10^{-07}\end{array}$ & $\begin{array}{l}2.8 \times 10^{-6} \\
\pm 0.25 \times 10^{-08}\end{array}$ & $\begin{array}{l}2.8 \times 10^{-6} \\
\pm 0.25 \times 10^{-08}\end{array}$ & $\begin{array}{l}2.8 \times 10^{-6} \\
\pm 0.25 \times 10^{-08}\end{array}$ & $\begin{array}{l}2.8 \times 10^{-6} \\
\pm 0.25 \times 10^{-08}\end{array}$ \\
\hline Group II & $\begin{array}{l}0.25 \times 10^{-6} \\
\pm 0.25 \times 10^{-08 \mathrm{a}^{* * *}}\end{array}$ & $\begin{array}{l}0 \\
\pm 0 \mathrm{a}^{* * *}\end{array}$ & $\begin{array}{l}2.8 \times 10^{-6} \\
\pm 0.25 \times 10^{-08} \mathrm{a}^{\mathrm{NS}}\end{array}$ & $\begin{array}{l}0.57 \times 10-6 \\
\pm 0.2 \times 10- \\
8 a^{* * *}\end{array}$ & $\begin{array}{l}0.57 \times 10-6 \\
\pm 0.2 \times 10-8 \mathrm{a}^{* * *}\end{array}$ & $\begin{array}{l}0.57 \times 10-6 \\
\pm 0.2 \times 10- \\
8 \mathrm{a}^{* * *}\end{array}$ \\
\hline Group III & 0 & $\begin{array}{l}2.8 \times 10^{-6} \\
\pm 0.25 \times 10^{-}\end{array}$ & 0 & 0 & 0 & 0 \\
\hline
\end{tabular}


Short term effects of Centella asiatica on methylparathion induced toxicity on different regions of the

\begin{tabular}{|c|c|c|c|c|c|c|}
\hline & $\pm 0 a^{* * *}$ & ${ }^{08} \mathrm{a}^{* * *}$ & $\pm 0 a^{* * * *}$ & $\pm 0 \mathrm{a}^{* * * *}$ & $\pm 0 a^{* * *}$ & $\pm 0 \mathrm{a}^{* * * *}$ \\
\hline Group IV & $\begin{array}{l}0 \\
\pm 0 \mathrm{a}^{* * *}\end{array}$ & $\begin{array}{l}0 \\
\pm 0 \mathrm{a}^{* * *}\end{array}$ & $\begin{array}{l}2.8 \times 10^{-6} \\
\pm 0.25 \times 10^{-} \\
{ }^{08} \mathrm{a}^{\mathrm{NS}} \mathrm{b}^{* * *}\end{array}$ & $\begin{array}{l}2.8 \times 10^{-6} \\
\pm 0.25 \times 10^{-} \\
{ }^{08} \mathrm{a}^{\mathrm{NS}} \mathrm{b}^{* * *}\end{array}$ & $\begin{array}{l}2.8 \times 10^{-6} \\
\pm 0.25 \times 10^{-08} \mathrm{a}^{\mathrm{NS} \mathrm{b}^{* * *}}\end{array}$ & $\begin{array}{l}0 \\
\pm 0 \mathrm{a}^{* * *}\end{array}$ \\
\hline Group V & $\begin{array}{l}0.25 \times 10^{-6} \\
\pm 0.25 \times 10^{-08} \text { aNs }\end{array}$ & $\begin{array}{l}0.83 \times 10^{-5} \\
\pm 0.26 \times 10^{-07} \text { a NS }\end{array}$ & $\begin{array}{l}2.8 \times 10^{-6} \\
\pm 0.25 \times 10^{-08} \mathrm{a}^{\mathrm{NS}}\end{array}$ & $\begin{array}{l}2.8 \times 10^{-6} \\
\pm 0.25 \times 10^{-} \\
{ }^{08} \mathrm{a}^{\mathrm{NS}}\end{array}$ & $\begin{array}{l}2.8 \times 10^{-6} \\
\pm 0.25 \times 10^{-08} \mathrm{a}^{\mathrm{NS}}\end{array}$ & $\begin{array}{l}2.8 \times 10^{-6} \\
\pm 0.25 \times 10^{-} \\
{ }^{08} \mathrm{a}^{\mathrm{NS}}\end{array}$ \\
\hline
\end{tabular}

Values represent mean \pm SD of 6 animals

$* * * \mathrm{p}<0.001 ; * * \mathrm{p}<0.01 ; * \mathrm{p}<0.05 ;{ }^{\mathrm{NS}}$ Non-significant

a when compared with group I b when compared with group II

Table - 4 Acetylcholinesterase (AChE) activity in the different regions of the brain Of Rattus norvegicus

\begin{tabular}{|c|c|c|c|c|c|c|}
\hline Parameter & OL & OP & CB & CL & MB & MO \\
\hline Group I & $\begin{array}{l}0.25 \times 10^{-6} \\
\pm 0.25 \times 10^{-08}\end{array}$ & $\begin{array}{l}0.83 \times 10^{-5} \\
\pm 0.26 \times 10^{-07}\end{array}$ & $\begin{array}{l}2.8 \times 10^{-6} \\
\pm 0.25 \times 10^{-08}\end{array}$ & $\begin{array}{l}2.8 \times 10^{-6} \\
\pm 0.25 \times 10^{-08}\end{array}$ & $\begin{array}{l}2.8 \times 10^{-6} \\
\pm 0.25 \times 10^{-08}\end{array}$ & $\begin{array}{l}2.8 \times 10^{-6} \\
\pm 0.25 \times 10^{-08}\end{array}$ \\
\hline Group II & $\begin{array}{l}0 \\
\pm 0 \mathrm{a}^{* * *}\end{array}$ & $\begin{array}{l}2.8 \times 10^{-6} \\
\pm 0.25 \times 10^{-08} \mathrm{a}^{* * *}\end{array}$ & $\begin{array}{l}2.8 \times 10^{-6} \\
\pm 0.25 \times 10^{-08} \text { aNS }\end{array}$ & $\begin{array}{l}0 \\
\pm 0 \mathrm{a}^{* * *}\end{array}$ & $\begin{array}{l}0 \\
\pm 0 \mathrm{a}^{* * *}\end{array}$ & $\begin{array}{l}2.8 \times 10^{-6} \\
\pm 0.25 \times 10^{-08} \text { aNs }\end{array}$ \\
\hline Group III & $\begin{array}{l}2.8 \times 10^{-6} \\
\pm 0.25 \times 10^{-08} \mathrm{a}^{* * *}\end{array}$ & $\begin{array}{l}2.8 \times 10^{-6} \\
\pm 0.25 \times 10^{-08} \mathrm{a}^{* * *}\end{array}$ & $\begin{array}{l}2.8 \times 10^{-6} \\
\pm 0.25 \times 10^{-08} \mathrm{aNS}\end{array}$ & $\begin{array}{l}2.8 \times 10^{-6} \\
\pm 0.25 \times 10^{-08} \text { aNS }\end{array}$ & $\begin{array}{l}2.8 \times 10^{-6} \\
\pm 0.25 \times 10^{-08} \text { aNS }\end{array}$ & $\begin{array}{l}2.8 \times 10^{-6} \\
\pm 0.25 \times 10^{-08 \mathrm{a}^{* * *}}\end{array}$ \\
\hline Group IV & $\begin{array}{l}2.8 \times 10^{-6} \\
\pm 0.25 \times 10^{-} \\
{ }^{08} \mathrm{a}^{* * *} \mathrm{~b}^{* * *}\end{array}$ & $\begin{array}{l}2.8 \times 10^{-6} \\
\pm 0.25 \times 10^{-} \\
{ }^{08} a^{*} * * b^{N S}\end{array}$ & $\begin{array}{l}2.8 \times 10^{-6} \\
\pm 0.25 \times 10^{-08} \text { aNS bNS }\end{array}$ & $\begin{array}{l}2.8 \times 10^{-6} \\
\pm 0.25 \times 10^{-08} \text { aNS } \\
\mathrm{b}^{* * * *}\end{array}$ & $\begin{array}{l}2.8 \times 10^{-6} \\
\pm 0.25 \times 10^{-08} \text { aNS b** }\end{array}$ & $\begin{array}{l}2.8 \times 10^{-6} \\
\pm 0.25 \times 10^{-08} \text { aNs } \\
\text { bNS }\end{array}$ \\
\hline Group V & $\begin{array}{l}0.25 \times 10^{-6} \\
\pm 0.25 \times 10^{-08} \text { aNS }\end{array}$ & $\begin{array}{l}0.83 \times 10^{-5} \\
\pm 0.26 \times 10^{-07} \mathrm{aNS}\end{array}$ & $\begin{array}{l}2.8 \times 10^{-6} \\
\pm 0.25 \times 10^{-08} \text { aNS }\end{array}$ & $\begin{array}{l}2.8 \times 10^{-6} \\
\pm 0.25 \times 10^{-08} \text { aNS }\end{array}$ & $\begin{array}{l}2.8 \times 10^{-6} \\
\pm 0.25 \times 10^{-08} \text { aNS }\end{array}$ & $\begin{array}{l}2.8 \times 10^{-6} \\
\pm 0.25 \times 10^{-08 \mathrm{aNS}}\end{array}$ \\
\hline
\end{tabular}

Values represent mean \pm SD of 6 animals

$* * * \mathrm{p}<0.001 ; * * \mathrm{p}<0.01 ; * \mathrm{p}<0.05 ;{ }^{\text {NS }}$ Non-significant

a when compared with group I $b$ when compared with group II

Figure - 1 Acetylcholinesterase (AChE) activity in the different regions of the brain Of rat Rattus norvegicus due to short term oral toxicity on $7^{\text {th }}$ day

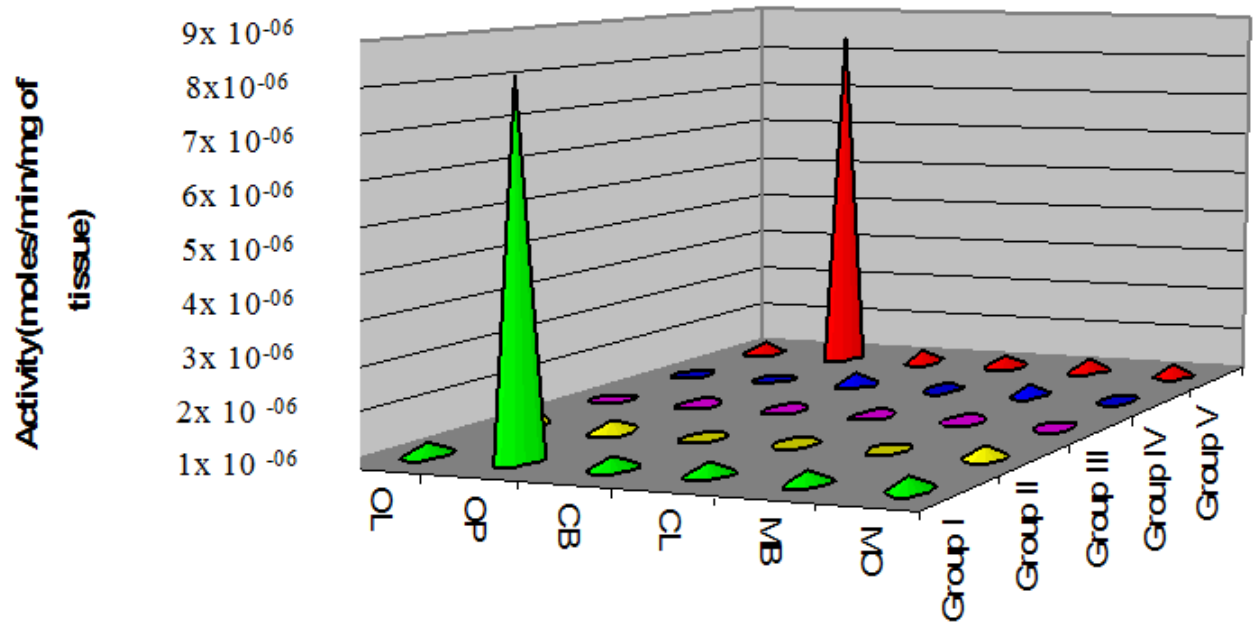

Group I $\square$ Group II $\square$ Group III $\square$ Group IV $\square$ Group V 
Figure - 2 Acetylcholinesterase (AChE) activity in the different regions of the brain Of rat Rattus norvegicus due to short term oral toxicity on $14^{\text {th }}$ day

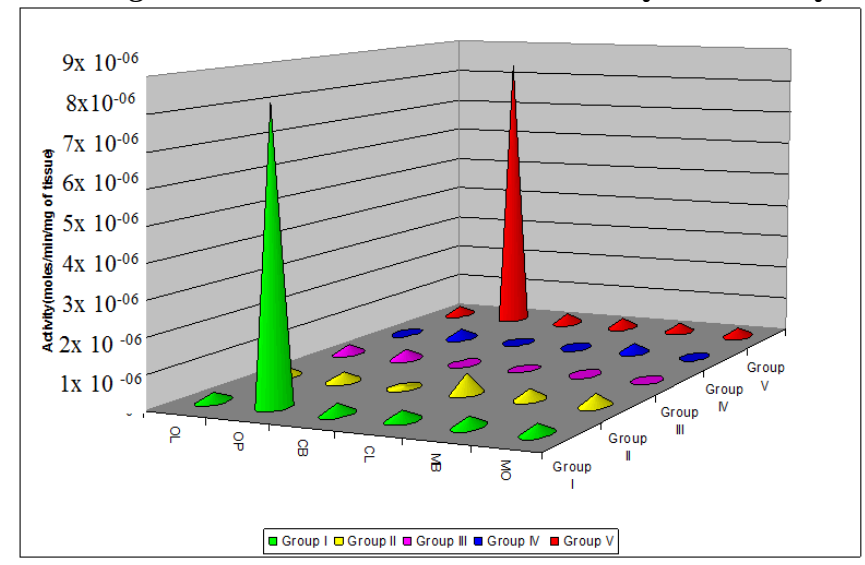

Figure - 3 Acetylcholinesterase (AChE) activity in the different regions of the brain Of rat Rattus norvegicus due to short term oral toxicity on $21^{\text {st }}$ day

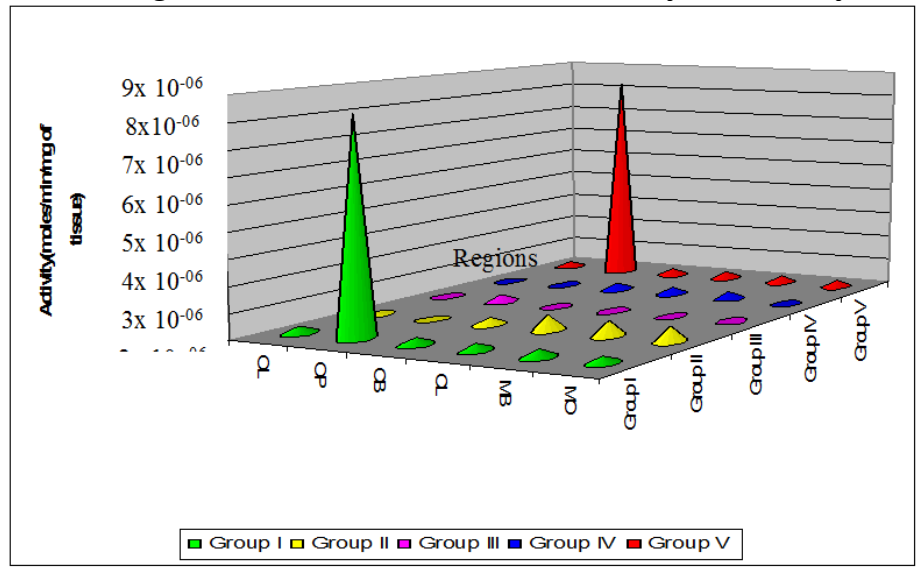

Figure - 4 Acetylcholinesterase (AChE) activity in the different regions of the brain Of rat Rattus norvegicus due to short term oral toxicity on $28^{\text {th }}$ day

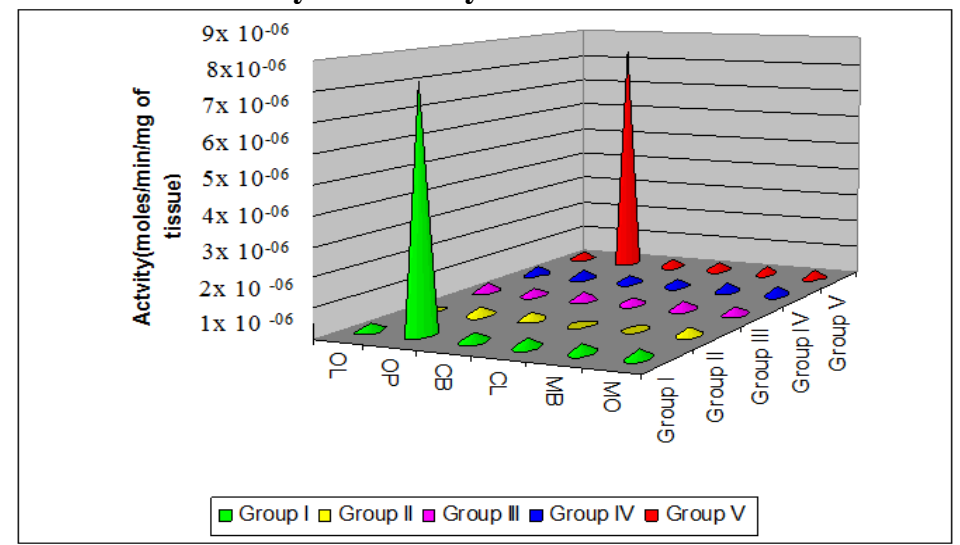

\section{Acknowledgements:}

This work is supported by BTISnet Centre sponsored by Department of Biotechnology, Ministry of Science \& Technology, Government of India 


\section{References:}

[1]. Kalender, Y., Uzunhisarcikli, M., Ogutcu, A., Acikgoz, F. and Kalender, S. 2006. Effects of diazinon on pseudocholinesterase activity and haematological indices in rats: The protective role of Vitamin E. Environmental Toxicology and Pharmacology, 22: 4651.

[2]. Karanth,S., Liu .J., Jr Oliver, K. and Pope, C. 2004. Interactive toxicity of the Organophosphorus insecticides chlorpyrifos and methyl parathion in adult rats. Toxicol. and appl. Pharmacol., 196:183-190.

[3]. Pope, C.N. 1999. Organophosphorus pesticides: Do they all have the same mechanism of toxicity. J. Toxicol. Environ. Health, Part B2: 101-121.

[4]. Ecobichon, D.J. 1996. Toxic effects of pesticides. In: Klassen, C.D. (ed.), Casarett and Doull's Toxicology, $5^{\text {th }}$ (ed)., McGraw Hill, New York, pp. 643-698.

[5]. Gallo, M.A. and Lawryk, N.J. 1991.Organic phosphorus pesticides. In: Hayes Jr., W.J. and Laws Jr., E.R. (eds.), Handbook of pesticide toxicology; Classes of pesticides, vol.2, Academic press, New York, pp. 917-1123.

[6]. Vijayan, V.K. and Brownson, R.H 1975. polyarylamide gel electrophoresis of rat brain acetylcholinesterase isoenzymal changes following parathion poisoning. J.Neurochem., 24:105-110.

[7]. Ellman,G.L., Courtney, K.D., Andres. and Featherstone, R.M. 1961. A new and rapid colorimetric determination of acetylcholinesterase activity. Biochem.pharmacol., 7:88-95.

[8]. Dikshith, T. S. S., Datta, K. K. and Raizada, R. B. 1982. Effect of repeated oral administration of quinalphos to male goat (Capra hircus). J. Biosci., 4(4): 405-411.

[9]. Sayim, F., Yuvasoglu, N. U. K., Uyanikgil, Y., Aktug, H.,Yavasoglu, A. and Turgut, M. 2005. Neurotoxic effects of cypermethrin in wistar rats: A haematological, biochemical and histopathological study. J. of Health. Sci., 5(13): 300- 307.

[10]. Aziz, M.H., Agarwal, A.K., Adhami, V.M., Shukla, Y. and Seth, P.K. 2001. Neurodevelopmental consequences of gestational exposure (GD14-GD20) to low dose deltamethrin in rats. Neurosci. Lett.,300:161- 165.

[11]. Husain, R., Husain, R., Adhami, V.M. and Seth, P.K. 1996. Behavioral, neurochemical and neuromorphological effects of deltamethrin in adult rats. J. Toxicol. Environ. Health, 48: $515-526$.

[12]. Rao, S. B., Chetana, M. and Uma Devi, P. 2005. Centella asiatica treatment during postnatal period enhances learning and memory in mice. Physiology and Behavior, 86: $449-457$.

[13]. Savolainen, K. 2001. Understanding the toxic actions of organophosphates. In: Krieger, R (ed.), Handbook of pesticide toxicology. Agents, vol.2. Academic press, New York, pp.1013-1036.

[14]. Silver, A. 1974. Frontiers of Biology: The Biology of Cholinesterases, vol. 36. North -Holland, Amsterdam.

[15]. Norman,B.J.,Poore,R.E. and Neal,R.A.1974. Studies of the binding of sulfur released in the mixed function oxidase-catalysed metabolism of diethyl P-nitrophenyl phosphorothioate (parathion) to diethyl p-nitrophenyl phosphate (pan).Biochem.Pharmacol., 23:1733-1744.

[16]. Neal, R.A. 1967. Studies on the metabolism of diethyl-4-nitrophenyl phosphorothioate (parathion) in vitro. Biochem.J., 108: 183-191.

[17]. Saunders, D.S. and Harper, C.1994. Pesticides. In: Hayes, A.W. (Ed.), Principles and Methods of Toxicology, $3^{\text {rd }}$ (ed)., Raven Press, New York, pp.389-426.

[18]. Lima, D.S.J., Neto, B.C.D.J., Bastos, C.D.F.L.V., Cunha, D.C.J., Morates, M.D.F.F., Ferreira, A.F.D.M., Moreira, C.D.J. and Faria, C.D.V.M. 1996. Methyl parathion activation by a partially rat brain fraction. Toxicol. Lett., 87:53-60.

[19]. Marrs,T.C. 1993. Organophosphate poisoning. Pharmac. Ther., 51-66.

[20]. Koelle, G.B. 1992. Pharmacology and toxicology of organophosphates.. In: Ballantyne B. and Marrs, T.C. (eds.)., Clinical and Experimental Toxicology of organophosphates and carbamates, Butterworth-Heinemann, Oxford, pp.33-37.

[21]. Rickett, D.L., Gleen, J.F. and Beers, E.T. 1986. Central respiratory effects versus neuromuscular actions of nerve agents. Neurotoxicology, 7:225-236.

[22]. Casarett, L. J. and Doull, J. 1980. Toxicology: The Basic Science of Poisons. Macmillian publishing co., inc.New York, pp. 417. 